\title{
LIABILITY OF THE PRESIDENT IN LITHUANIA. THE CASE OF PRESIDENT ROLANDAS PAKSAS
}

\author{
M. Simion
}

\section{Mihaela Simion}

Faculty of Law and Social Sciences, the Law and Administrative Sciences Departament "1 December 1918" University, AlbaIulia, Romania

*Correspondence: Mihaela Simion, "1 December 1918" University, 5 Gabriel Bethlen St., Alba Iulia, Romania

E-mail: mihaelamacavei@yahoo.com

\begin{abstract}
The purpose of this paper is to analyse the legal framework of liability of the president in Lithuania. The particular interest for this model is due to the fact that Lithuania was the first and only (until this year) European Union member country where the procedure of impeachment of the President was finished by his dismissal. More specifically, in 2004, Rolandas Paksas became the first European president who was dismissed as a result of triggering the constitutional impeachment proceedings.

In the present context, when the liability of the Heads of State is increasingly questioned, the Lithuanian case is worth being evoked and known, because it represents a benchmark for all those who are preoccupied, theoretically or practically, by this matter.
\end{abstract}

Keywords: president, immunity, liability, impeachment, dismissal.

\section{Introduction}

Following the declaration of independence from the Soviet Union, Lithuania adopted a constitution in 1992, which set up an attenuated semi-presidential regime.

According to Article 78 of the fundamental law, the head of the Lithuanian state is the president, elected by universal, equal and direct suffrage, for a five-year term. In order to fulfil his duties, which are quite numerous and regulated by Article 84, the President issues decrees, among these only that of appointing and recalling the diplomatic representatives, conferring the highest military ranks, declaration the state of emergency state and granting the Lithuanian citizenship. All these decrees shall be countersigned by the First Minister and by the appropriate Minister.

\section{The immunity of the Lithuanian President}

During his office, the president enjoys immunity, Article 86 stipulating that his person is inviolable: he cannot be arrested and he shall not be held criminally or administratively liable.

The protection of the presidential office requires equally the avoidance of the impunity of the President himself, while his acts or conducts, fulfilled or shown throughout his tenure, appear clearly incompatible with the normal exercise and dignity of his office. The President shall not be prevented in any way to perform his office, instead the person holding the office must be submitted for dismissal if he does not perform his duties or if he performs it inappropriately. Thus, assuming that a President exercises the powers of his function for purposes or limits other than those established by the Constitution, the enjoyed immunity may be rebutted by training its liability according to procedures defined by the Constitution ${ }^{1}$.

\footnotetext{
${ }^{1}$ P. Ségur, La responsabilité politique. Que sais-je?, PUF, Paris, 1998, p. 17.
} 
This possibility is perfectly illustrated in the case of the President of Lithuania, Rolandas Paksas, subject to impeachment proceedings in 2004.

\section{Regulation of the liability of the Lithuanian President}

According to the same Article 86 of the Constitution of Lithuania, the President of the Republic may be removed from office, before the end of the term, only for serious violation of the Constitution, breach of the oath he took when he was invested, or when it transpires that a crime has been committed. His removal will be decided by the Lithuanian Parliament (Seimas), as stipulated by Article 74 of the Constitution and widely regulated by the Statute of Seimas, Part VIII, Chapters XXXVIII and XXXIX, Articles 227-243.

Therefore, we find ourselves in the presence of a liability that has a constitutional nature and that was triggered both for serious violation of the Constitution or breach of oath, and for committing any punishable acts by the criminal law.

According to Article 74 of the Constitution of Lithuania, the President of the Republic (...) may be removed from office, by a majority of $3 / 5$ of the total number of the legislative assembly, as stipulated by the removal proceedings regulated by the Statute of the Seimas.

The impeachment is initiated on the proposal of at least $1 / 4$ of the members of the Seimas, and where there is a suspicion that the president had committed an offense, the Prosecutor General shall promptly inform the Seimas. Hearing this, the legislature shall form a special commission of inquiry, which will be composed of a maximum of 12 parliamentarians belonging both to the power and opposition, according to its political configuration. Once with the formation of the commission, the Seimas shall also appoint its chairman and vice-chairman, and shall set a deadline for completing the parliamentary investigation (Article 232 of the Statute of the Seimas).

The sittings of the special investigation commission shall be held behind closed doors, but all discussions will be recorded in writing by the secretary of the commission. The arguments and explanations of the President shall be heard, the witnesses shall be questioned, any evidence that seems appropriate shall be produced, experts and specialists shall be invited if necessary. The representative of the President shall be entitled to attend all the sittings of the commission (Article 233 of the Statute).

The chairman of the Commission or another member authorised by him shall inform mass media about the course of the investigation (Article 234 of the Statute).

The report of the special investigation of the commission shall include, mainly, the Commission proposal on initiation the impeachment proceedings, the concrete circumstances of committing the indicted felony, the explanations of the President of the Republic (Article 236 of the Statute). To be approved, the report must meet the vote of half plus one of the commission members and, then, must be signed by the chairman and the vice-chairman of the commission.

The approved report and any other relevant documents shall be submitted by the commission to the president of the Seimas in order to be presented to the plenary of the representative assembly, at the next meeting.

If the Seimas, by the majority of vote of the present members, approve the report of the special investigation commission which concluded that there are no grounds for initiation of impeachment proceedings, or, does not approve the report that pronounces in favour of impeachment, it shall adopt a resolution of concluding the investigation proceedings. Also, the Seimas may decide on completion or restoration of the investigation by the same commission or by a new one appointed for this purpose (Article 238 of the Statute of the Seimas).

Conversely, if the Seimas approves by a majority of the vote of the present parliamentarians the report of the investigation commission that is favourable to start the impeachment proceedings, it shall adopt a resolution of initiating the procedure and request, in writing, the Constitutional Court to express its opinion in that case. 
The impeachment procedure against the Lithuanian President will continue its course only if the Constitutional Court decides that the concrete actions of the head of state are in conflict with the Constitution, or, more precisely, those actions had as result a serious breach of the provisions of the fundamental law, breach of the investment oath in office or a felony (Article 238 of the Statute of the Seimas). If the conclusions of the Constitutional Court establish that the concrete actions of the President do not infringe the Constitution, the Seimas shall adopt a decision to stop the dismissal procedure (Article 240 paragraph 7 of the Statute).

Taking note of the approval of the Constitutional Court to continue the procedure for dismissal, the Seimas shall determine the date of the sitting to discuss the charges that are made to the President. It must be informed in writing of the date of the debates.

The president will have the right to take part to the sitting of the Seimas in person or to nominate a representative. Also, he will be entitled to more lawyers, whose names must be communicated with at least two days prior to any hearing, so that they can be invited in writing to the Seimas sitting.

On the occasion of the hearing, the President and his defenders may offer evidence considered to be significant for the constitutional responsibility by the members of the legislative assembly. If the President and his defenders do not present themselves to debates, without a serious reason, this situation does not represent an impediment to the development of the case.

The Seimas sitting that will question the dismissal of the President of the Republic shall be public, being transmitted by radio and national television (Article 240 paragraph 2 of the Statute of the Seimas). The debates are opened by the Chairman who will read a report on the findings of the Constitutional Court. Only for strong reasons he can decide to postpone the hearings.

The President of the Republic has the right to speak to the Seimas, or, upon request, one of his lawyers will speak. The chairman of the sitting and the defenders will be able to ask questions. The members of the Seimas will be able to ask questions to the president or to his lawyer only with the permission of the Chairman.

The hearings will conclude with a final statement of the impeached President. Subsequently, the members of the Seimas will be able to speak, according to the ordinary parliamentary procedure.

After completing the discussions on the removal from office, the President or the Vice-President of the Seimas shall present to the parliamentarians a draft resolution for each charge separately, which shall contain the conclusions of the Constitutional Court, the decision of dismissing from office the President of the Republic, as well as the information that the resolution will produce effects from the day of its publication in the mass media.

The resolution on dismissal of the head of state will be taken if $3 / 5$ of all Seimas members votes in its favor. The President shall be deemed dismissed from the moment the resolution has been published in mass media. Also, he will have to undertake the responsibility for the offences committed under ordinary criminal laws (Article 242 of the Statute of the Seimas.

\section{The case of Rolandas Paksas}

The Lithuanian mechanism of liability of the President of the Republic has a particular importance given the fact that there was held the first impeachment proceedings concluded with the dismissal of the head of state in Europe.

In 2003, shortly after his election as President, Rolandas Paksas began to be suspected of links with the Russian mafia. In particular, the fact that drew the attention was that Paksas granted, by "exceptional" decree, the Lithuanian citizenship to Yuri Borisov, president of Avia Baltika company, who previously donated $\$ 400,000$ for his presidential election campaign. Notified by the Seimas, the Constitutional Court stated that the Lithuanian citizenship granting decree contradicts several constitutional provisions (Articles 29 paragraph 1,82 paragraph 1 and 84 paragraph 21), the rule of law and the law on citizenship. 
Even so, in December 2003, eighty-six members of the Seimas signed the proposal of initiation the impeachment proceedings of President Paksas. According to the Statute, the Seimas decided to form a special investigation commission to verify the reasonableness and seriousness of the charges brought to the head of state, and to determine if, indeed, the initiation of the impeachment proceedings is appropriated.

On 19 February 2004, the special investigation commission concluded that some of the charges brought to the President were founded and serious. It recommended to the Seimas to start the impeachment proceedings, which happened on the same day. So deciding, the Seimas asked the Constitutional Court to decide whether the deeds of the President of the Republic had as result the violation of the fundamental law.

The decision of the Constitutional Court of 31 May 2004 established that the head of state was guilty of serious violations of the Constitution, as well as the breach of the constitutional oath submitted on his appointment, given the following facts:

- granting unlawfully the Lithuanian citizenship to Y. Borisov by Decree no. 40, as a reward for the financial support;

- disclosure, knowingly, of some state secrets to the same Y. Borisov, including the actions of the state institutions of investigating the business man and the tapping of his telephone conversations;

- use of his official powers in order to influence the decisions of the management of a private company so as to provide material benefits to people close to him.

On 6 April 2004, the Seimas decided to dismiss the president in office for serious infringements of the Constitution, noticed by the Constitutional Court.

Subsequently to the dismissal, Paksas expressed his intention to run for the presidential elections, as consequence of the vacancy of the office in the manner shown above. In response to this action of Paksas, the Seimas amended the law on presidential elections, inserting a provision that prohibited the persons dismissed from office by the Seimas, as a consequence of impeachment proceedings, to be elected as President of the Republic for 5 years after their removal from office.

Following this amendment, the Central Election Committee refused to register Paksas' candidacy in the presidential election. However, the Seimas has asked the Constitutional Court to review the constitutionality of the amendment brought to the Election Law.

By its decision, the Court held that it was constitutional to prevent the presidential candidacy of a person dismissed from public office, but it was unconstitutional to stipulate the time of 5 years for prohibition. So deciding, the Constitutional Court underlined that a person who was removed from the office of president for a serious violation of the Constitution or for breach of an oath, should not ever be elected as President of the Republic, member of the Seimas and should never be able to hold any public office for which it was necessary to take the oath prescribed by the Constitution.

Paksas's dismissal for the incriminating facts established by the Constitutional Court had consequences in the criminal proceedings, too. Lacking immunity, the former president was indicted for disclosing classified information as a state secret. The Court of Vilnius acquitted him in October 2004 for lack of evidence. Yet, this decision was invalidated by the Court of Appeal, which found Paksas guilty, but did not applied him any criminal penalty, holding that the dismissal from office and prohibition of running for a public office involving the provision of an oath were sufficient. In December 2005, the Supreme Court of Lithuania quashed the decision of the Court of Appeal, confirming the acquittal solution given by the Court of Vilnius. 
In 2011, the European Court of Human Rights has found the life ban to run for a public office applied to the former President Rolandas Paksas being disproportionate and thus contrary to the European Convention on Human Rights ${ }^{2}$.

\section{Concusions}

The Lithuanian example confirms the trend of reaffirming the liability principle of the heads of state, as well as the identification concerns of a more precise and effective correlation between the powers held and exercised by the head of state, on the one hand, and his responsibility, on the other hand.

In Lithuania, the breach of legal and constitutional provisions, the abusive exercise of duties, led to the impeachment of the President by the Seimas, the Lithuanian Parliament and, subsequently, his judgment by the Constitutional Court. The sanction imposed by the Constitutional Court of Lithuania was a political one: the dismissal, which, however, did not rule out in principle the application of other penalties, civil or criminal. Only the penalty infringing the exercise on voting rights, particularly the right to be elected to public functions applied to the ousted President is considered abusive in the legal vision of the European Court of Human Rights.

\section{Bibliography}

European Court of Human Rights, Paksas versus Lithuania, case no. 34932/2004;

Ségur, P., La responsabilité politique. Que sais-je?, PUF, Paris, 1998;

Constitution of the Republic of Lithuania, 1992, www.lrs.lt;

Seimas of the Republic of Lithuania Satute, www.lrs.lt.

\footnotetext{
${ }^{2}$ European Court of Human Rights, Paksas versus Lithuania, case no.34932/2004.
} 